\title{
TP53BP2 Gene
}

National Cancer Institute

\section{Source}

National Cancer Institute. TP53BP2 Gene. NCI Thesaurus. Code C18367.

This gene plays an inhibitory role in G2/M cell cycle progression and stimulates the transactivation of pro-apoptotic genes. 